\title{
Nitrate Nutrition and Temperature Effects on Wheat: a Synthesis of Plant Growth and Nitrogen Uptake in Relation to Metabolic and Physiological Processes
}

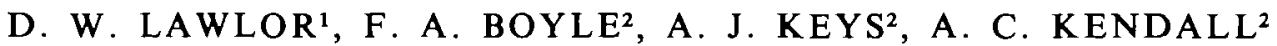 \\ AND A. T. YOUNG ${ }^{1}$ \\ ${ }^{1}$ Department of Physiology and Environmental Physics, AFRC Institute of Arable Crops \\ Research, Rothamsted Experimental Station, Harpenden, Herts. AL5 2JQ, U.K.
}

${ }^{2}$ Department of Biochemistry, AFRC Institute of Arable Crops Research, Rothamsted Experimental Station, Harpenden, Herts. AL5 $2 J Q, U . K$.

Received 10 September 1987

\begin{abstract}
Lawlor, D. W., Boyle, F. A., Keys, A. J., Kendall, A. C. and Young, A. T. 1988. Nitrate nutrition and temperature effects on wheat: a synthesis of plant growth and nitrogen uptake in relation to metabolic and physiological processes.-J. exp. Bot. 39: 329-343.

Growth of spring wheat was measured in $\operatorname{cool}\left(13^{\circ} \mathrm{C}\right.$ day $/ 10^{\circ} \mathrm{C}$ night $)$ or warm $\left(23^{\circ} \mathrm{C} / 18^{\circ} \mathrm{C}\right)$ temperatures, combined with large and small amounts of nitrate fertilizer. The rate of growth of dry matter was less at cool temperatures but total growth over the same period of development was slightly greater in the cool than in the warm. Main-shoot and tiller leaves grew slower and, despite growing for a longer period, were shorter in the cool than in the warm. They had greater fresh and dry mass and content of starch and fructosans per unit area. Cool conditions increased root dry mass, root to shoot ratio and nitrogen content in dry matter. Additional nitrate increased leaf area of main shoots slightly but of tillers greatly; it increased leaf and tiller dry matter and total plant dry mass. Additional nitrate decreased the proportion of dry matter in roots and in stems and the $\mathrm{N}$ content of dry matter in all plant parts. Regulation of growth by temperature, nitrate supply and the rôle of photosynthesis and nitrogen uptake, is considered in relation to the mechanisms of incorporation of carbon and nitrogen into biochemical constituents. It is concluded that temperature regulates the rate of protein synthesis, which determines plant growth rate. Nitrogen flux into the plant is not directly linked to protein synthesis so that the content of $\mathrm{NO}_{3}^{-}$ and of amino acids is related both to growth and to conditions governing $\mathrm{NO}_{3}^{-}$uptake and its reduction. When nitrogen supply is large, growth is limited by temperature, not $\mathrm{NO}_{3}^{-}$. Inadequate nitrate supply decreases protein synthesis (and therefore growth) more than it decreases carbon assimilation, so that organs such as roots and stems increase in dry matter relative to shoots and all tissues have smaller proportions of nitrogen in dry matter. Cool conditions, although decreasing the rate of protein synthesis, increase its duration and decrease the size of leaves, so that the content of protein per unit leaf area is greater in cool than in warm grown leaves. Consequences of changes in the balance of $\mathrm{N}$ and $\mathrm{C}$ supply and growth rate for dry matter distribution in plants are discussed.
\end{abstract}

Key words-Wheat, nitrate nutrition, temperature.

Correspondence to: Department of Physiology and Environmental Physics, AFRC Institute of Arable Crops Research, Rothamsted Experimental Station, Harpenden, Herts. ALS 2JQ, U.K. 


\section{INTRODUCTION}

Nitrate fertilization is the most widely used method of stimulating plant growth (Vesk, Possingham, and Mercer, 1965; Dale, 1979). The mechanisms by which nitrate changes biochemical processes through increasing amino acid synthesis and stimulation of the production of enzymes, pigments etc. have been much studied (Beevers, 1979) and a coherent picture of the rôle of enzymes of nitrate and nitrate reduction in amino acid synthesis and the dependence on photosynthetic light reactions and carbon assimilation has emerged (Stulen, 1986). However, there is less understanding of how biochemical processes integrate to produce differences in composition and physiological function of leaves and other organs and, ultimately, plant growth. There is also uncertainty about the way the environment influences the mechanisms controlling plant production and the distribution of carbon and nitrogen into organs ('partitioning'); these processes determine the efficiency of plant production and yield. Understanding the interactions between temperature, nitrogen supply and plant processes may contribute to more efficient use of nitrogen in agricultural systems and to optimization of amount and quality of economic yield by correct timing of nitrogen supply in relation to organ growth.

This paper describes the effects of two temperatures and two rates of nitrate supply on growth of spring wheat and relates growth to leaf composition and carbon and nitrogen metabolism, described by Lawlor, Boyle, Kendall and Keys, 1987a; Lawlor, Boyle, Young, Keys, and Kendall, 1987b; Lawlor, Boyle, Young, Kendall, and Keys, 1987c, in a qualitative model of the integrated plant system.

\section{MATERIALS AND METHODS}

Details of growth conditions are given in Lawlor et al. (1987a). Briefly, plants of spring wheat (Triticum aestivum $\mathrm{L}$. var. Kolibri) were grown with two rates of nitrogen fertilizer designated $-\mathrm{N}$ $\left(0.9 \mathrm{mmol} \mathrm{NO}--\right.$ at sowing and $0.45 \mathrm{mmol} \mathrm{NO}_{3}^{-}$twice weekly for 4 weeks) and $+\mathrm{N}(3.9 \mathrm{mmol} \mathrm{NO}-$ at sowing and $2.0 \mathrm{mmol} \mathrm{NO}{ }_{3}^{-}$twice weekly for 4 weeks) respectively, at temperatures of $13 / 10^{\circ} \mathrm{C}$ (day/night) or $23 / 18^{\circ} \mathrm{C}$ with $550 \mu \mathrm{mol}$ quanta $P A R \mathrm{~m}^{-2} \mathrm{~s}^{-1}$ for 6 weeks. After plant emergence, the increase in length of individual leaves was determined, at approximately daily intervals, as they emerged from the enclosing sheaths, by measuring the distance to the leaf tip from a reference point on the pot.

Plants from three replicate pots of each $\mathrm{N}$ and temperature treatment were sampled at two or three day intervals. Plants were cut off at the soil surface and divided into main shoots and tillers which were further sub-divided into stems and leaves. Roots were washed from the soil. Fresh mass of plant parts, leaf and stem areas and dry mass (after drying at $80^{\circ} \mathrm{C}$ for $24 \mathrm{~h}$ ) were determined. Growth rates were calculated according to standard equations. Total nitrogen content per unit dry matter was determined by Kjeldahl analysis, and nitrate and soluble components of tissues were measured as described by Lawlor et al. $(1987 a, b, c)$; starch was determined as glucose after hydrolysis by amyloglucosidase, and fructosans were determined colorimetrically with resorcinol.

\section{RESULTS}

\section{Plant growth}

Plants emerged after $3 \mathrm{~d}$ and $6 \mathrm{~d}$ in the warm and cool temperatures respectively. Rate of leaf elongation (Fig. 1) was faster in the warm than cool conditions, with a mean for leaves 2, 3 and 4 of $4.3 \mathrm{~cm} \mathrm{~d}^{-1}$ compared to $2.0 \mathrm{~cm} \mathrm{~d}^{-1}$, and duration of growth was 6.3 and $9.7 \mathrm{~d}$ respectively. Consequently mature leaves were $7.0 \mathrm{~cm}$ or $26 \%$ shorter in cool conditions. Nitrate deficiency did not alter the rate of leaf growth but shortened the duration by about $5 \%$ ( $10 \mathrm{~h}$ approximately) at both temperatures. Thus length of leaf 3 on the main shoots was not significantly decreased by low nitrate supply, but greatly by low temperature. After emergence of the third leaf, $11 \mathrm{~d}$ and $18 \mathrm{~d}$ after sowing (das) in the warm and cool temperatures, leaf expansion was completed by 17 and 29 das (mature 


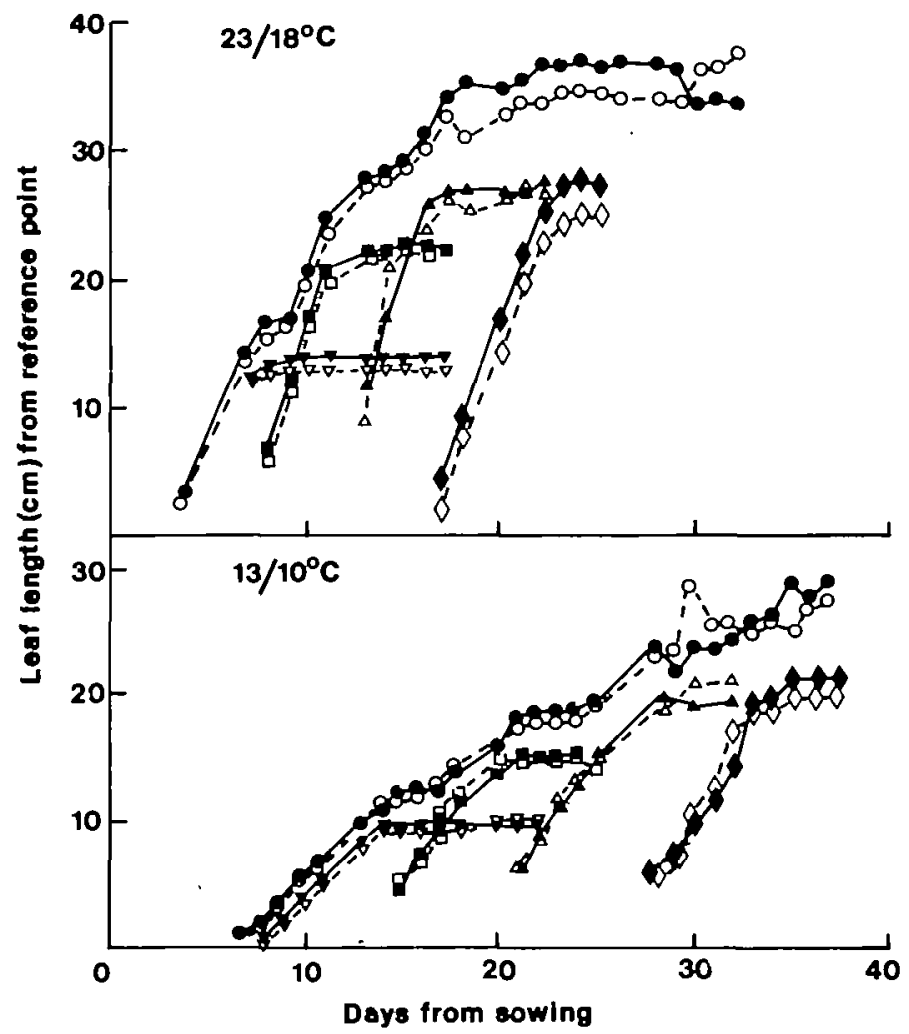

FIG. 1. Total plant height $(0, \bullet)$ and length of leaf $1(\nabla, \nabla), 2(\square, \nabla), 3(\Delta, \Delta)$ and $4(\bullet, \bullet)$ with age of wheat grown with nitrate (open symbols) and additional nitrate (solid symbols) at two temperatures.

Each point is the mean of at least 15 measurements on different plants.

leaves, see Lawlor et al., 1987a). Leaf senescence was less easily defined but the extent of laminar yellowing and tip death was comparable at 24 and 42 das (early senescent leaves) in the two temperatures, although delayed by extra nitrate.

Plant leaf area increased faster in warm conditions than cool (Fig. 2) and faster with additional nitrate. A total leaf area of $50 \mathrm{~cm}^{2}$ plant ${ }^{-1}$ was achieved, 21 and 36 das in warm and cool conditions respectively (Fig. 2a). With deficient N, $25 \mathrm{~d}$ were required in the warm, but this area was not produced in $50 \mathrm{~d}$ in the $\mathrm{C}-\mathrm{N}$ conditions. Differences in area between $\mathrm{N}$ levels were small in early growth (up to about 20 and $30 \mathrm{~d}$ in warm and cool conditions) when the seed provided the required $\mathrm{N}$, but later increased rapidly. Over the period from emergence to 35 and $50 \mathrm{~d}$ in the warm and cool conditions, leaf area increased by $3 \cdot 1$ and $2 \cdot 1 \mathrm{~cm}^{2} \mathrm{~d}^{-1}$ in the $+\mathrm{N}$ and $-\mathrm{N}$ treatments in the warm and by 1.6 and $1.0 \mathrm{~cm}^{2} \mathrm{~d}^{-1}$ in the respective nitrogen treatments in the cool. The mean relative growth rate of leaf area from 20 to $50 \mathrm{~cm}^{2}$ plant ${ }^{-1}$ was $0.153 \mathrm{~d}^{-1}$ and $0.108 \mathrm{~d}^{-1}$ in $\mathrm{W}+\mathrm{N}$ and $W-N$ respectively, and $0.065 \mathrm{~d}^{-1}$ in $C+N$. The relative growth rate from 20 to $40 \mathrm{~cm}^{2}$ per plant was $0.040 \mathrm{~d}^{-1}$ in $\mathrm{C}-\mathrm{N}$. Main-shoot leaf area (Fig. 2b) was greater in warm- than in cold-grown plants at equivalent development stages and increased by approximately $15 \%$ in the warm and $20 \%$ in the cool with additional nitrogen. Leaf area of tillers (Fig. 2c) showed the greatest difference; warm grown plants produced tillers earlier, but at similar accumulated temperature to cool grown. With $+\mathrm{N}$ these grew faster in the warm than in the cool temperature. Low $\mathrm{N}$ slowed growth of tillers similarly at both temperatures. Leaf 
fresh mass per unit area was slightly greater in cool than warm temperature $\left(200 \mathrm{~g} \mathrm{~m}^{-2}\right.$ cf. $185 \mathrm{~g} \mathrm{~m}^{-2}$ ) but nitrate had little effect. Leaf dry mass per unit area was similar in young leaves in all conditions (c. $28 \mathrm{~g} \mathrm{~m}^{-2}$ ), but in older plants mass per area for both main stem and tiller leaves was substantially greater in cool than warm conditions $\left(62 \mathrm{~g} \mathrm{~m}^{-2} \mathrm{cf} .50 \mathrm{~g}\right.$ $\mathrm{m}^{-2}$ averaged over both $\mathrm{N}$ treatments) and greater with $+\mathrm{N}\left(59 \mathrm{~g} \mathrm{~m}^{-2}\right)$ compared to $-\mathrm{N}$ $\left(55 \mathrm{~g} \mathrm{~m}^{-2}\right)$.

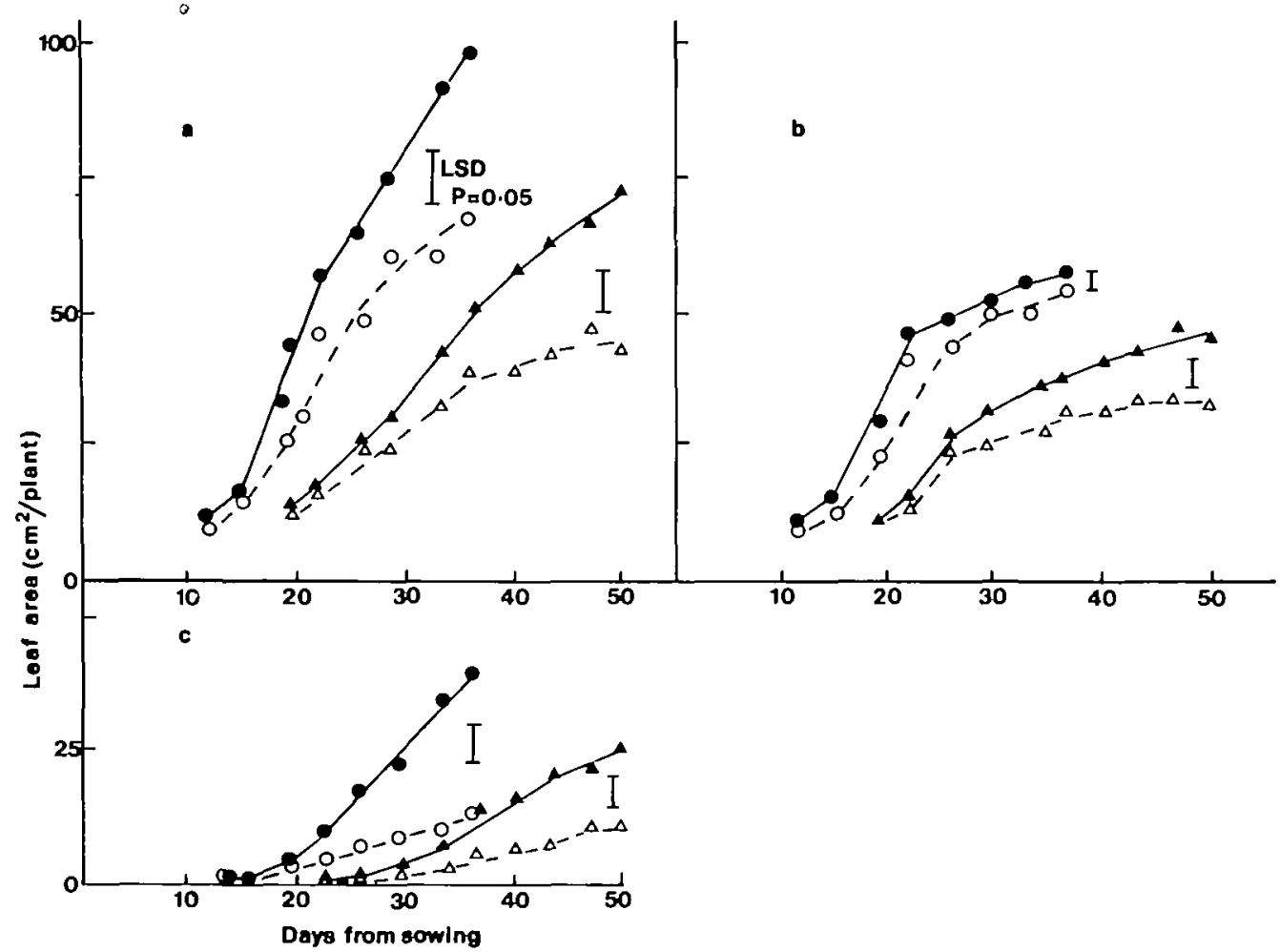

FIG. 2. Growth of (a) total, (b) main stem and (c) tiller leaf areas of wheat grown under two temperature regimes $13 / 10^{\circ} \mathrm{C}$ (day/night temperature, $\left.\Delta, \Delta\right)$ or $23 / 18^{\circ} \mathrm{C}(0, \bullet)$ and two nitrate amounts, basal nitrate (open symbols) and with $4 \times$ the basal amount (closed symbols) in relation to days from sowing.

Total dry mass of plants (Fig. 3a) was greater with additional $\mathrm{N}$ (but not significantly so in the warm), due mainly to the faster growth and greater dry mass of the tillers (Fig. $3 c, e)$; growth was faster in warm than cool conditions and differences in dry mass increased with time, particularly in the cool. Relative growth rate from 0.2 to $0.8 \mathrm{~g}$ dry mass was decreased in the warm from 0.107 to $0.099 \mathrm{~d}^{-1}$ with low $\mathrm{N}$ supply. In the cold the relative growth rate was 0.077 with additional $\mathrm{N}$ and $0.063 \mathrm{~d}^{-1}$ without. Main shoot dry mass (Fig. 3b) was little affected by nitrogen supply with small differences showing only in the warm treatment late in growth. Root dry mass (Fig. 3d) increased faster in warm than cool conditions but there was no effect of nitrogen. Dry mass of leaves on the main stems and particularly on tillers (Fig. 3e) increased earlier and faster in the warm compared with cool, and with $+\mathrm{N}$ compared with $-\mathbf{N}$. However, dry mass of main stems was greater with deficient $\mathrm{N}$ at both temperatures, whereas tiller stems were heavier with additional N. Ratio of tiller to main stem dry matter was substantially increased by additional nitrate 


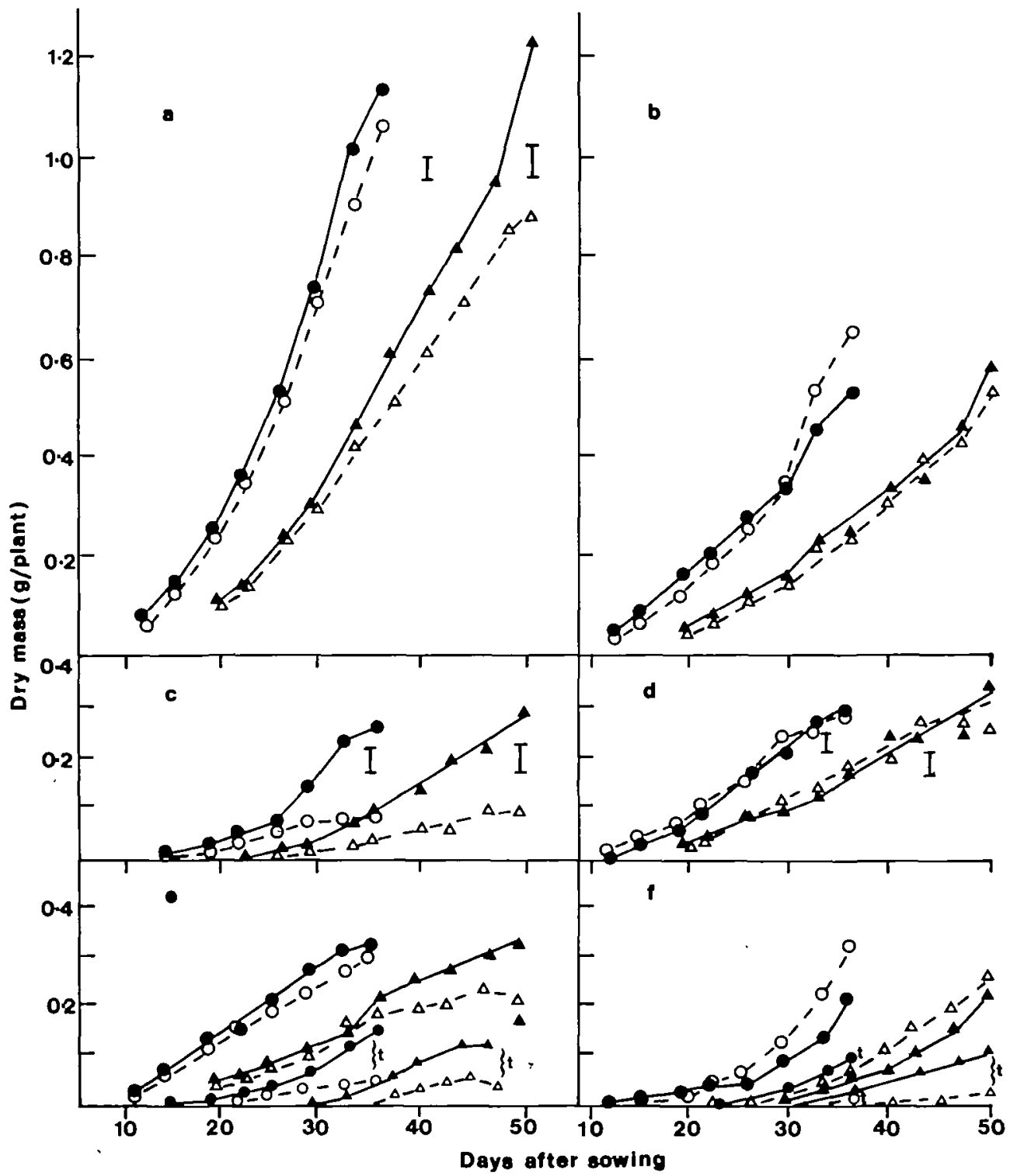

Fig. 3. Dry mass of (a) whole plant, (b) main shoot, (c) tillers, (d) roots, (c) mainstem and tiller leaves, (f) main stem and tiller stems of wheat, with age. Growth conditions and symbols as shown in Fig. 2, except that tillers are marked with a $t$ in (e) and (f).

in both temperatures. The ratio of root to shoot dry matter was greater with low nitrate and in cool conditions in young plants $(0 \cdot 85)$ compared to the warm with additional nitrogen (0.6); it decreased with age in all treatments remaining larger in the cool and with deficient $\mathbf{N}$.

Dry matter accumulation is the result of assimilation exceeding respiration. As temperature affects many of the processes responsible for dry matter growth (leaf area growth, duration of the assimilatory period, efficiency of assimilation, etc.), the net effect on the whole system may be compared by examining the relation of dry matter to 
accumulated temperature sum above $0{ }^{\circ} \mathrm{C}$. Per unit of accumulated temperature $\left({ }^{\circ} \mathrm{C} . \mathrm{d}\right)$, dry matter per plant (Fig. 4) was greater in cold than in warm conditions just after germination and the difference increased as the plants grew. Nitrogen deficiency slowed accumulation of dry matter as the plants aged. Total plant mass increased approximately linearly over the range $250-500{ }^{\circ} \mathrm{C} . \mathrm{d}$ in cool and $400-700{ }^{\circ} \mathrm{C} . \mathrm{d}$ in warm conditions, and was greater in cool than warm and with $+\mathrm{N}$. Growth rates were $c .2 \cdot 9,2 \cdot 5,2 \cdot 6$ and $2 \cdot 3 \mathrm{mg}$ plant ${ }^{-1}\left({ }^{\circ} \mathrm{C} . \mathrm{d}\right)^{-1}$ in $\mathrm{C}+\mathrm{N}, \mathrm{C}-\mathrm{N}, \mathrm{W}+\mathrm{N}$ and $\mathrm{W}-\mathrm{N}$ treatments respectively. Tillers grew at $0.80,0.36,0.80$ and $0.26 \mathrm{mg}$ plant $^{-1}\left({ }^{\circ} \mathrm{C} . \mathrm{d}\right)^{-1}$ in the same treatments. Total leaf area (Fig. 4b) of young plants grew at a similar rate, $0.2 \mathrm{~cm}^{2}$ plant ${ }^{-1}\left({ }^{\circ} \mathrm{C} . \mathrm{d}\right)^{-1}$ in both cool and warm conditions with additional nitrate. The mean rate of leaf area growth decreased by c. $35 \%$ to $0.13 \mathrm{~cm}^{2}$ plant $^{-1}\left({ }^{\circ} \mathrm{C} . \mathrm{d}\right)^{-1}$ with nitrate deficiency in the warm-grown plants and by $12 \%$ to $0.18 \mathrm{~cm}^{2}$ plant $^{-1}\left({ }^{\circ} \mathrm{C} . \mathrm{d}\right)^{-1}$, in the $\mathrm{C}-\mathrm{N}$ treatment. As the plants aged, leaf growth was progressively restricted by deficient nitrate supply.

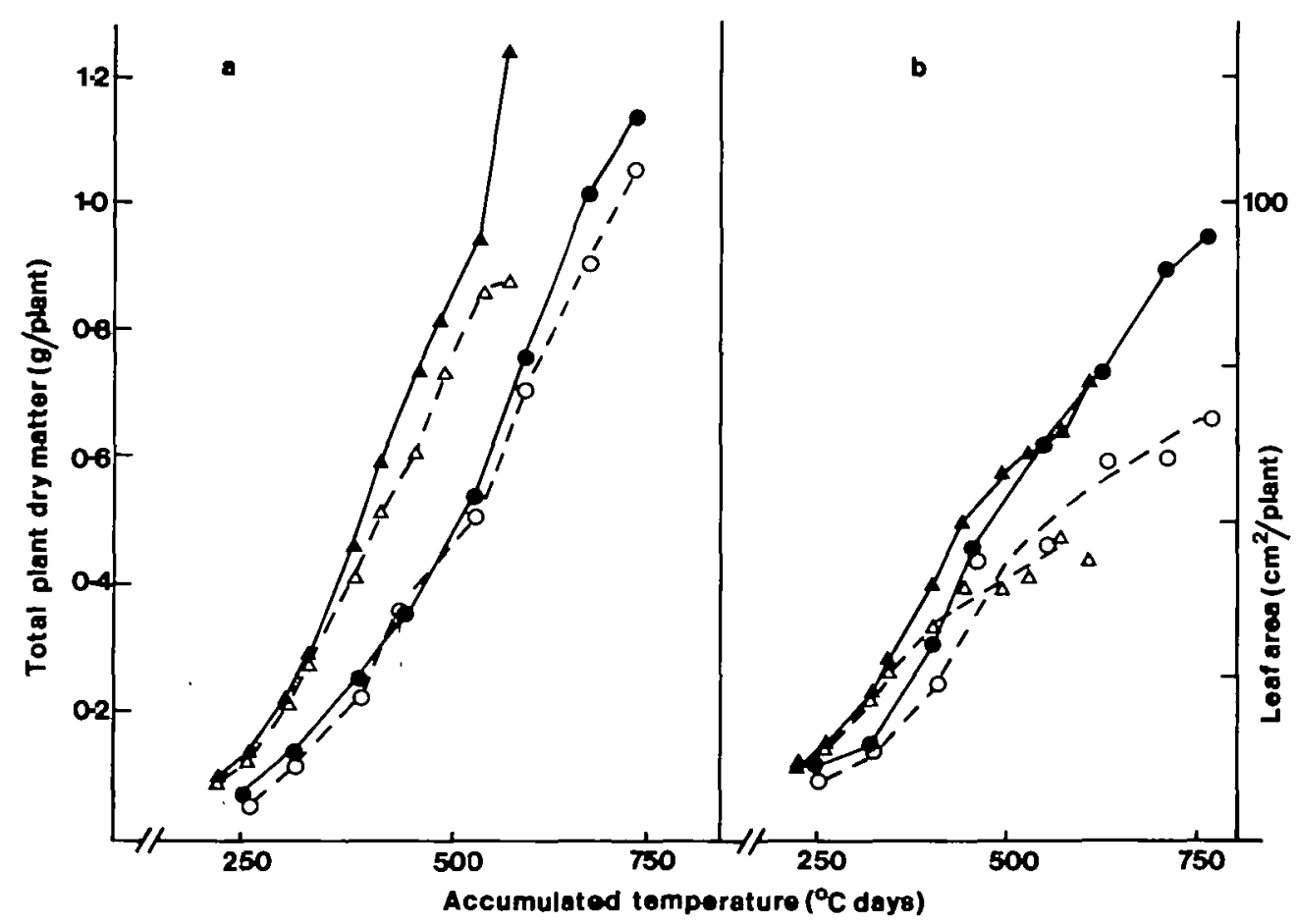

FIG. 4. (a) Total dry matter accumulation and (b) leaf area growth of plants grown in cool and warm temperatures with two rates of nitrogen supply as a function of accumulated temperature. Symbols as in Fig. 2.

Photon flux per day was the same in all conditions, but as plants in the warm grew faster than in the cool their efficiency of light utilization (per unit of total available photons) was greater. Growth from 0.2 to $0.8 \mathrm{~g}$ dry matter had an efficiency of $0.0015 \mathrm{~g}$ mol-1 $^{-1} P A R$ photons incident on unit ground area in $\mathrm{W}+\mathrm{N}$, and low $\mathrm{N}$ reduced it by c. $10 \%$. Cool conditions decreased efficiency by approximately $35 \%$ at both $N$ levels. This decrease is similar to the decreased rate of leaf area development, suggesting that efficiency of light utilization was similar in all treatments, as observed by Lawlor et al. $(1987 b)$. 


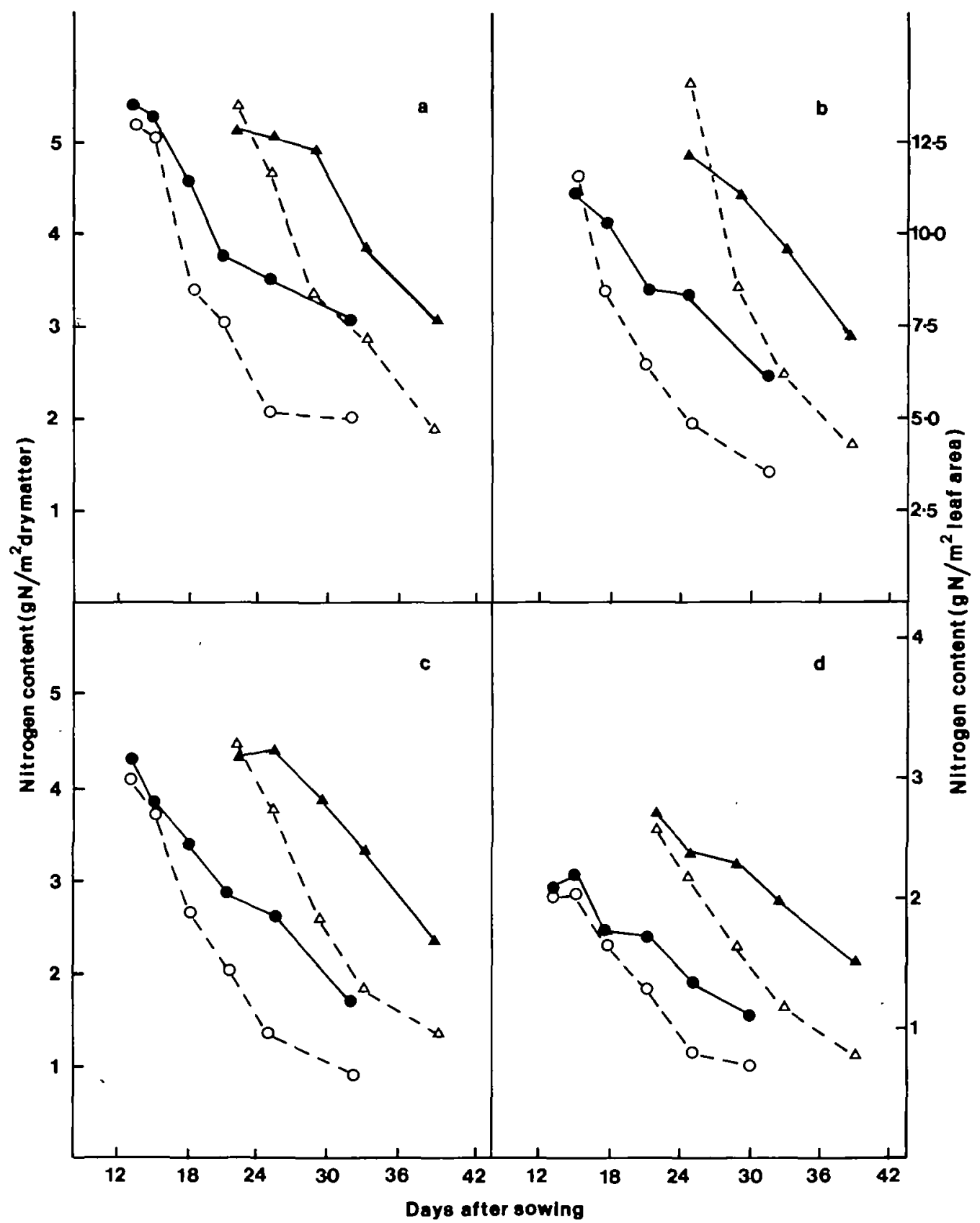

Fig. 5. Total nitrogen content in dry matter (and the equivalent content per unit area) of (a) main stem leaves, (b) tillers, (c) main stem stems, (d) roots, with age of wheat plants grown under the conditions described with symbols in Fig. 2.

\section{Nitrogen and nitrate content}

The total $\mathrm{N}$ concentration per unit dry matter of young main-shoot leaf (Fig. 5a) and stem (Fig. 5c) was similar in all treatments, but young tillers (Fig. 5b) and roots (Fig. 5d) had a smaller content of $\mathrm{N}$ in warm than cold conditions. Main-shoot and tiller leaves 
had larger $\mathrm{N}$ contents than stems and roots had the lowest. Nitrogen content of all organs decreased with age in all treatments, but more without additional nitrate. Total $\mathrm{N}$ content per unit of leaf area ranged from $130 \mathrm{mmol} \mathrm{m}^{-2}$ in young leaves in both nitrate treatments, to 75 and $50 \mathrm{mmol} \mathrm{m}^{-2}$ in $+\mathrm{N}$ and $-\mathrm{N}$ treatments in older leaves at both temperatures.

Data for the nitrate nitrogen content of tissues is not presented in full (see Lawlor et al., 1987a); in mature leaves it was greatest in warm conditions (c. $3.5 \mathrm{mmol} \mathrm{NO}_{3}^{-} \mathrm{m}^{-2}$ ), but in $\mathrm{C}+\mathrm{N}$ conditions the maximum was $3.0 \mathrm{mmol} \mathrm{m}^{-2}$ and in $\mathrm{C}-\mathrm{N}$ less than $1.0 \mathrm{mmol}$ $\mathrm{m}^{-2}$. In nearly senescent leaves, nitrate content was less than $0.5 \mathrm{mmol} \mathrm{m}^{-2}$ and similar in all treatments. Except in very old leaves, the $+\mathrm{N}$-grown plants always contained more nitrate than $-\mathrm{N}$ and this was also true in tillers, stems and roots. The nitrate content of dry matter increased in the order roots (maximum of $0.15 \mathrm{mmol} \mathrm{kg}^{-1}$ dry matter in $\mathrm{C}+\mathrm{N}$ ) $<$ stems $<$ tillers $<$ leaves.

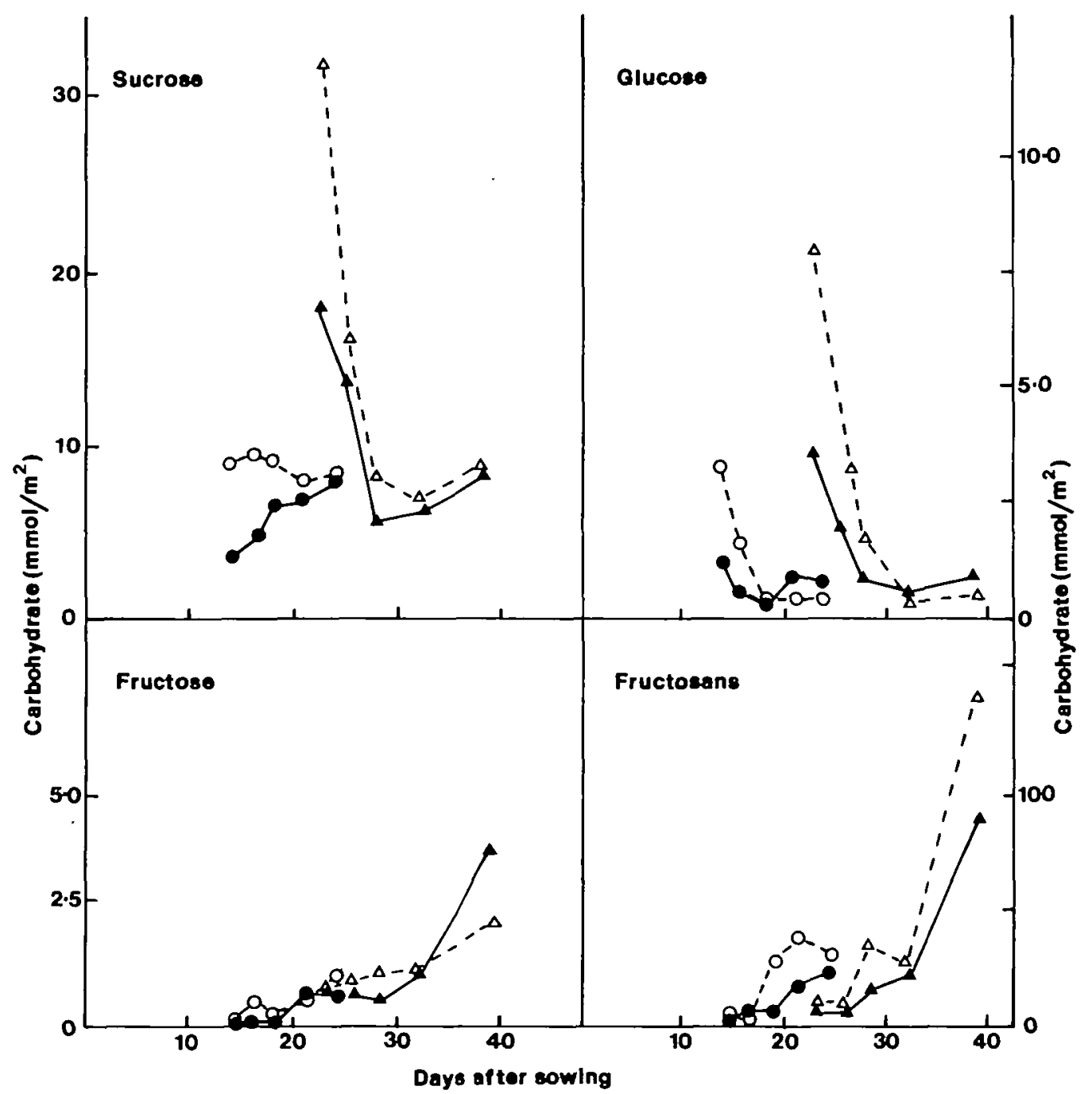

FIG. 6. Changes in carbohydrates in total leaf material with age of wheat grown in two temperatures and with two nitrate supplies as described in legend to Fig. 2. 


\section{Carbohydrate content}

Sucrose content per unit area of leaf from young plants (Fig. 6a) differed greatly with treatment, with much greater content when grown in cool than warm conditions. Additional nitrate decreased the amount of both temperatures in young and mature leaves, but as leaves aged the amounts became similar in all treatments. Glucose (Fig. 6b) was most abundant in expanding or mature leaves, particularly those grown under cool nitratedeficient conditions, but the decrease with age was similar in early senescent leaves in all treatments. In contrast, free fructose (Fig. $6 \mathrm{c}$ ) increased as leaves aged, particularly in $\mathrm{C}+\mathrm{N}$ plants. Fructosans (Fig. 6d) and starch (data not shown, see Lawlor et al., 1987c) also increased as leaves aged, particularly in the low nitrate treatments.

\section{DISCUSSION}

The maximum rate of growth of plants, the 'growth potential', is genetically determined and varies greatly between species. This potential is regulated by environmental conditions, particularly by temperature and the supply of assimilated carbon and nitrogen compounds to the growing organs, in a manner characteristic of the plant species. Evidence from many sources (Durzan and Steward, 1983) has shown that the growth potential is regulated at the level of protein synthesis, which is the primary process controlling plant growth. Temperature is the main environmental factor acting on protein synthesis, probably via enzymes of the transcription and translation mechanisms. Supplying large amounts of substrates required for growth (e.g. amino acids for protein synthesis and carbohydrates for cell constituents and energy) to plants, cells or isolated biochemical systems limited in growth by temperature, does not increase growth rate. Thus the temperature limitation is a fundamental one and the formation of enzymatic and structural proteins is a sine qua non for the development of cell and plant structure. We, therefore, assume that protein

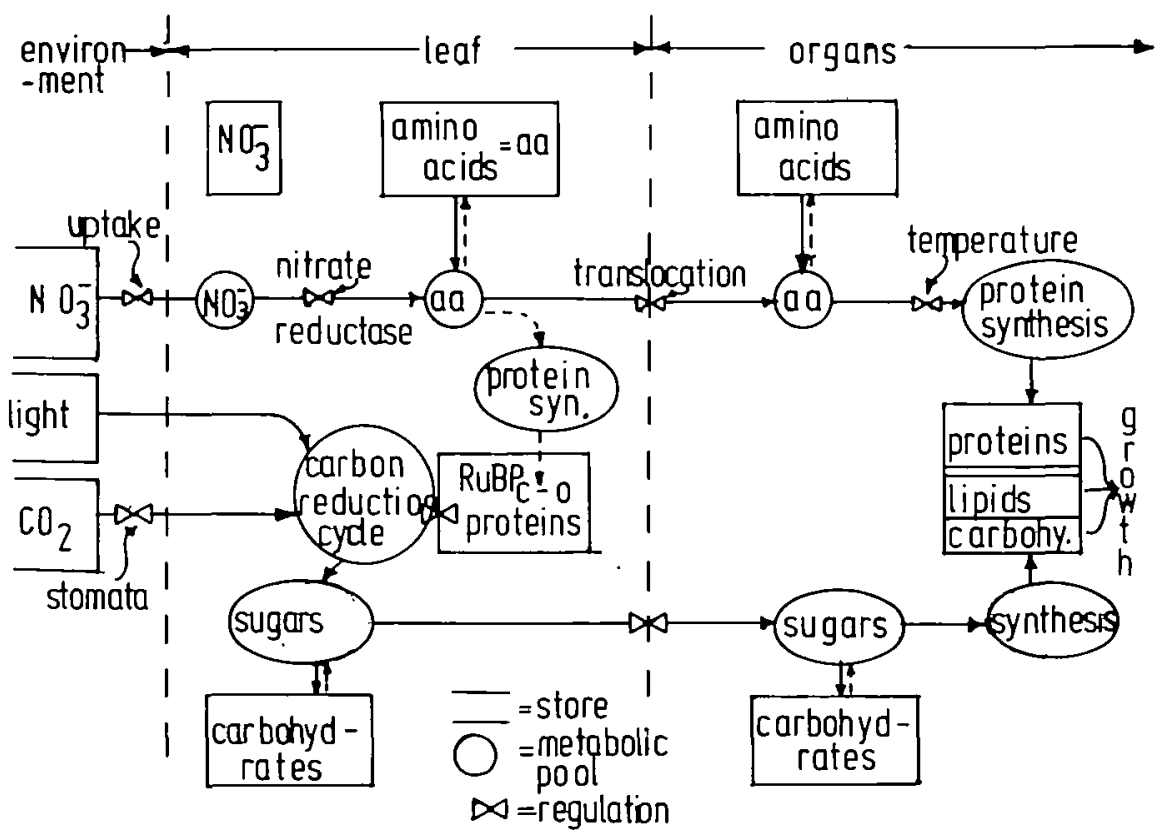

Fig. 7. Scheme of $\mathrm{C}$ and $\mathrm{N}$ fluxes in metabolic and storage pools of tissue components, leading from the environmental supply through production of substrates in the leaf, to growth of organs. 
synthesis constitutes the 'driving variable' in growth. Complex feedback mechanisms acting on plant development and structures, via processes in carbohydrate and amino acid synthesis, regulate and control plant composition and growth rate. This concept is summarized and illustrated in Fig. 7 which shows the main fluxes of $\mathrm{C}$ and $\mathrm{N}$ in the plant and the relation between pools of tissue components.

During early growth, seed reserves of protein provide the amino acids essential for growth of the first two leaves of the plant described in this study (Lawlor et al., 1987a). With the formation of functional leaf area, $\mathrm{CO}_{2}$ and $\mathrm{NO}_{3}^{-}$assimilation, driven by light energy, provide for subsequent growth of organs (Beevers, 1979). However, the rates of supply of light energy and of $\mathrm{NO}_{3}^{-}$and $\mathrm{CO}_{2}$ to the plant interact with temperature to give a particular growth rate; with inadequate substrate supply, actual growth rates are smaller than potential. This argument identifies temperature as regulating plant growth rate, which is determined genetically at the level of protein synthesis. The studies reported here and previously (Lawlor et al., 1987a, b,c) provide information to support this hypothesis and evidence of the mechanism by which $\mathrm{NO}_{3}^{-}$supply regulates growth. The data show the response of the plant in terms of the size and proportion of the organs, the 'partitioning' of assimilates and they provide mechanisms which explain, semi-quantitatively, changes in $\mathrm{N}$ and $\mathrm{C}$ distribution.

\section{Protein synthesis}

The mean rate of protein synthesis in leaves for each treatment may be estimated from the protein content of the mature third leaf (largely dependent on exogenous $\mathrm{N}$ supply), the area of the leaf and the duration of the period from leaf initiation to maturity, estimated by extrapolation of leaf length with time to start of elongation (Fig. 1). From the values used (Table 1), cold conditions decreased the rate by about $60 \%$ in both $\mathrm{N}$ treatments compared with warm; low $\mathrm{N}$ supply decreased the net rate of protein synthesis per leaf by $40 \%$ in the warm and $52 \%$ in the cold. The apparent anomaly of larger protein content in mature leaves (Lawlor et al., 1987a) from cold-compared to warm-grown plants, yet a slower rate of protein synthesis, is related to the longer duration of synthesis and the relative size of leaves; those from cool conditions are $30 \%$ smaller in $+\mathrm{N}$ and $40 \%$ in $-\mathrm{N}$, so the protein is packed into a smaller area. This implies that cell number or size or arrangement are controlled (Dale, 1979) independently of the rate of protein synthesis.

The rate of protein synthesis (Table 1) was 2-3-fold greater in $\mathbf{W}+\mathbf{N}$ than $\mathrm{C}-\mathrm{N}$ treatments, whereas plant growth rate was 1.9 -fold greater. In the $\mathbf{W}-\mathbf{N}$ treatment protein synthesis and plant growth rates were 2.8 and $2 \cdot 4$-fold greater than in the $\mathrm{C}-\mathrm{N}$. The much larger rates of protein synthesis require faster flux of $\mathrm{N}$ from the soil to protein, and $\mathrm{NO}_{3}^{-}$deficiency is reflected in slower growth, although protein synthesis and growth

TABLE 1. Estimation of the rate of net protein synthesis in the third leaf on the main shoot of wheat plants grown at two temperatures and with two rates of $N$ supply

\begin{tabular}{lclcc}
\hline Treatment & Cold $-\mathrm{N}$ & $\mathrm{C}+\mathrm{N}$ & Warm $-\mathrm{N}$ & $\mathrm{W}+\mathrm{N}$ \\
\hline Leaf protein content $\left(\mathrm{g} \mathrm{m}^{-2}\right)$ & 7 & 12 & 5 & 8 \\
Area leaf $3\left(\mathrm{~cm}^{2}\right)$ & 9.9 & $12 \cdot 0$ & 16.5 & $17 \cdot 1$ \\
Duration of leaf growth (d) & 12 & 12 & 5 & 5 \\
Rate of protein synthesis & 0.58 & 1.20 & 1.65 & $2 \cdot 74$ \\
$\quad\left(\mathrm{mg} \mathrm{leaf}-1 \mathrm{~d}^{-1}\right)$ & & & & \\
\hline
\end{tabular}


are not proportional. Growth is less affected by low $\mathbf{N}$ than protein synthesis because of redistribution of $\mathbf{N}$ between organs and changed ratio of $\mathrm{N}$ to total dry matter. Leaf 3 was much less affected by $\mathrm{N}$ deficiency than protein synthesis because, presumably, the leaf area was determined whilst more $\mathrm{N}$ was available, hence the non-significant difference between $\mathbf{W}-\mathbf{N}$ and $\mathbf{W}+\mathrm{N}$ leaf area. Cereals form leaves and tiller buds at a rate dependent on temperature but largely independent of nutrition (Kirby, 1985). Nitrogen supply, however, determines the rate of tiller growth which, from the data shown in this paper, is more sensitive to $\mathrm{NO}_{3}^{-}$deficiency than is growth of main stems. Over longer periods the effects of deficiency become amplified. Not only is growth of leaf area slowed by $\mathrm{NO}_{3}^{-}$ deficiency, but the rate of senescence increases, thus further decreasing leaf area. However, $\mathrm{N}$ is recycled to the growing leaves thus maintaining a relatively large photosynthetic rate per unit of area (Lawlor et al., 1987b). In our experiments faster growth in the warm increased the demand for $\mathrm{NO}_{3}^{-}$and hence deficiencies appeared earlier than in the cold.

\section{Growth rates and $N$ supply}

Growth rates calculated for the change in dry mass from 0.2 to $0.8 \mathrm{~g}$ (Table 2) were larger in warm than in cool conditions. Nitrate deficiency decreased growth rate more in warm than cool conditions, similar to the effect on protein synthesis (Table 1), and also decreased the $\mathbf{N}$ uptake rate. However, the increased growth rate with additional $\mathbf{N}$ ( $c$. $25 \%$ in the warm and $55 \%$ in the cool) was much smaller than the increase in $\mathrm{N}$ uptake rate (2.6 and 3.4-fold in warm and cool respectively) suggesting that with abundant $\mathrm{N}$ the $\mathbf{N}$ flux was not limiting growth rate, which was a function of temperature. However, with the smaller $\mathrm{NO}_{3}^{-}$application (Table 2) plant growth rate was significantly smaller in warm than cool conditions as expected if demand for nitrate exceeded supply. The large contents of $\mathrm{NO}_{3}^{-}$and amino acids in the $+\mathrm{N}$ treatments support the concept that the $\mathrm{NO}_{3}^{-}$uptake mechanism functions to maintain the content of $\mathrm{N}$ substrates in excess of the demands for protein synthesis even at warm temperature, i.e. the rate of growth is 'sink' limited with abundant $\mathbf{N}$ but 'source' limited when $\mathbf{N}$ is deficient.

TA BLE 2. Plant growth rate, relative growth rates and nitrogen uptake rate calculated from experimental data for wheat grown at two different temperatures and with two rates of nitrate supply, described in the legend to Fig. 2

\begin{tabular}{|c|c|c|c|c|}
\hline & $\mathrm{C}-\mathrm{N}$ & $\mathrm{C}+\mathrm{N}$ & $\mathrm{W}-\mathbf{N}$ & $\mathbf{W}+\mathbf{N}$ \\
\hline $\begin{array}{l}\text { Plant growth rate } \\
\left(\text { g plant }{ }^{-1} \mathrm{~d}^{-1} \times 10^{-2}\right)\end{array}$ & $2 \cdot 2$ & $3 \cdot 4$ & $5 \cdot 2$ & 6.5 \\
\hline $\begin{array}{l}\mathrm{N} \text { uptake rate } \\
\left(\mu \mathrm{mol} \mathrm{Ng}^{-1} \text { dry mass } \mathrm{d}^{-1}\right)\end{array}$ & 25 & 85 & 50 & 130 \\
\hline $\begin{array}{l}\text { Relative growth rate } \\
\qquad\left(\mathrm{g} \mathrm{g}^{-1} \mathrm{~d}^{-1}\right)\end{array}$ & 0.054 & 0.07 & $0 \cdot 10$ & $0 \cdot 11$ \\
\hline
\end{tabular}

\section{Nitrogen incorporation}

Increasing availability of $\mathrm{NO}_{3}^{-}$stimulates the flux of carbon from $\mathrm{CO}_{2}$ to amino acids, as shown by ${ }^{14} \mathrm{C}$ incorporation (Lawlor et al., 1987c). It is of interest to relate the differences in $\mathrm{C}$ flux to amino acids to the nitrogen content of the tissues grown under the different conditions. Assuming that the steady-state flux of ${ }^{14} \mathrm{C}$ into amino acids (given by the incorporation during $10 \mathrm{~min}$ of exposure to ${ }^{14} \mathrm{CO}_{2}$ in the light) represents the rate of 
amino acid synthesis, then the $\mathrm{N}$ content may be calculated. Thus in the $\mathrm{W}+\mathrm{N}$ treatment for each $100 \mathrm{~mol} \mathrm{CO}_{2}$ assimilated, $28 \%$ of $\mathrm{C}$ enters amino acids, which contain approximately $16 \% \mathrm{~N}$, equivalent to $4.5 \mathrm{~mol} \mathrm{~N}$ or $63 \mathrm{~g} \mathrm{~N}$. Of the $72 \mathrm{~mol} \mathrm{C}$ in carbohydrates, about $25 \%$ (Table 3) is lost in respiration, i.e. $18 \mathrm{~mol} \mathrm{CO}_{2}$, so about $54 \mathrm{~mol} \mathrm{CO}_{2}$ is 'net fixation' equivalent to $1570 \mathrm{~g}$ dry matter. Thus the $\mathrm{N}$ content of the tissue is $63 \div 1570$ $=4 \%$. For a low $\mathrm{N}$ plant with $18 \%$ of ${ }^{14} \mathrm{CO}_{2}$ entering amino acids, giving $2.9 \mathrm{~mol} \mathrm{~N}$ and a net accumulation of $c .60 \mathrm{~mol} \mathrm{CO}$, the $\mathrm{N}$ content is $2 \%$ in dry matter. Higher rates of respiration will reduce the dry matter but not affect $\mathrm{N}$ accumulation so increasing the $\mathrm{N}$ content. The calculated incorporation of $\mathrm{N}$ is similar to measured values suggesting that incorporation of $\mathrm{C}$ into amino acids may be used to assess the adequacy of amino acid synthesis in plants.

TABLE 3. Calculated assimilation and respiration rates of wheat plants for periods $19-32 d$ and $26-47 \mathrm{~d}$ after sowing at $23 / 18^{\circ} \mathrm{C}$ and $13 / 10^{\circ} \mathrm{C}$ (day/night) temperatures, $W$ and $\mathrm{C}$ respectively and with or without additional nitrate $(-N$ and $+N)$

Values of plant mass, photosynthesis and respiration rates for the day/night periods, used to calculate net dry matter accumulation, are given.

\begin{tabular}{|c|c|c|c|c|}
\hline Treatment & $\mathrm{C}-\mathrm{N}$ & $\mathrm{C}+\mathrm{N}$ & $\mathbf{W}-\mathbf{N}$ & $\mathbf{W}+\mathrm{N}$ \\
\hline \multicolumn{5}{|l|}{ Assimilation } \\
\hline \multicolumn{5}{|l|}{ Mean assimilation rate $(\mathbf{P n})$} \\
\hline$\left(\mu \mathrm{mol} \mathrm{m} \mathrm{m}^{-2} \mathrm{~s}^{-1}\right)$ & 7 & 9 & 8 & 11 \\
\hline Leaf area $\left(\mathrm{m}^{2} \times 10^{-4}\right)$ & 34 & 44 & 44 & 62 \\
\hline Time (d) & 21 & 21 & 13 & 13 \\
\hline \multicolumn{5}{|l|}{ Total assimilation } \\
\hline \multicolumn{5}{|l|}{ Respiration } \\
\hline Mean mass (g) of plant & 0.52 & 0.60 & 0.33 & 0.68 \\
\hline Non-leaf mass (g) & 0.39 & 0.45 & 0.26 & 0.51 \\
\hline \multicolumn{5}{|l|}{$\begin{array}{l}\text { Respiration rate } \\
\left(\mu \mathrm{g} \mathrm{CO} \mathrm{g}^{-1} \text { dry wt. } \mathrm{s}^{-1}\right)\end{array}$} \\
\hline Leaf (night) & 0.45 & 0.53 & $1 \cdot 10$ & $1 \cdot 20$ \\
\hline Non-leaf (day) & 0.45 & 0.50 & $1 \cdot 10$ & $1 \cdot 30$ \\
\hline (night) & $0 \cdot 30$ & 0.35 & 0.70 & 0.80 \\
\hline \multicolumn{5}{|l|}{ Net respiration } \\
\hline (g dry matter) & 0.21 & 0.28 & 0.21 & 0.48 \\
\hline Calculated net dry matter ( $(\mathrm{g})$ & 0.65 & $1 \cdot 12$ & 0.57 & 1.02 \\
\hline Measured net dry matter (g) & 0.57 & 0.70 & 0.67 & 0.85 \\
\hline
\end{tabular}

The $\mathrm{N}$ content (mainly in proteins) of organs differs greatly according to their function. Roots and stems have an $\mathrm{N}$ content about half that of leaves. As roots and stems form about $75 \%$ of the total dry matter (Table 3), the $\mathrm{N}$ in leaf tissue would be expected to be about $40 \%$ of the total plant $\mathrm{N}$ and $\mathrm{N} \%$ in leaves of $\mathrm{W}+\mathrm{N}$ plants would be about $6 \%$ (in agreement with measured values in young tissues) and roots and stems would contain approximately $2 \cdot 5 \% \mathrm{~N}$, again similar to those measured.

Rapid growth increases the demand for $\mathrm{NO}_{3}^{-}$, and if this demand is not met, protein synthesis decreases. However, the existing photosynthetic system maintains the formation of carbohydrate (Lawlor et al., 1987c) which accumulates in storage organs (Fig. 7). Thus, the proportion of leaf-to-shoot plus stem dry matter and the shoot- to root-ratio both 
decrease. In older leaves the loss of nitrate reductase activity but maintenance of some photosynthesis (Lawlor et al., 1987a, $b$ ) also allows formation of carbohydrates but reduces that of amino acids and this, combined with remobilization of protein from older tissues to younger organs, decreases the nitrogen content relative to the amount of carbohydrates (cell walls etc.); hence with age the proportion of $\mathrm{N}$ in plant dry matter decreases. The older leaf, therefore, ceases to be a sink for $\mathrm{N}$ which may stop competition between organs of different ages. The partitioning of dry matter and $\mathrm{N}$ between organs (Lambers, Simpson, Beilharz, and Dalling, 1981) is related to the supply of substrates and competition for them. Thus young, growing, main-shoot leaves must compete with established organs and growing tillers for $\mathbf{N}$ to maintain growth. With slow accumulation of $\mathrm{N}$, recycling of $\mathrm{N}$ from older to younger tissues enables main-shoot leaves to grow and to maintain a relatively large protein content and thus assimilation rate per unit area. However, this occurs at the expense of growth of the rest of the plant e.g. tillers are suppressed. Mechanisms by which particular organs achieve and maintain dominance are largely unknown, with hormonal control possibly interacting with the substrate supply.

\section{Growth and dry matter accumulation}

Cool conditions slowed the rate of growth compared to warm, but increased it (Fig. 4) when expressed in relation to accumulated temperature. To understand how processes interact to determine dry weight we have estimated dry matter production under the nitrate and temperature treatments using short-term photosynthetic (and respiration) rates, leaf area, etc. and information from the assimilation of ${ }^{14} \mathrm{CO}_{2}$ (Lawlor et al., 1987c). Dry matter production between $19 \mathrm{~d}$ and $32 \mathrm{~d}$ in the warm and $26 \mathrm{~d}$ and $47 \mathrm{~d}$ in the cold (i.e. from approximately 0.25 to $1.0 \mathrm{~g}$ dry matter with a leaf area of $c .30$ to $60 \mathrm{~cm}^{2}$ ) has been calculated using the mean leaf area over the period and the rate of $\mathrm{CO}_{2}$ assimilation per unit leaf area at the growth temperature. Respiration rates per unit mass of shoot dry matter were measured (Robson and Parsons, 1981) on plant samples treated similarly but not as part of the same experiment. Total respiration for all non-photosynthetic tissue (and for leaves in darkness) was calculated using the mean dry matter during the period. For interconversions of $\mathrm{CO}_{2}$ and dry matter it is assumed that $1.5 \mathrm{~g} \mathrm{CO}_{2}$ is equivalent to $1.0 \mathrm{~g}$ of dried plant material. Agreement between the calculated dry mass accumulation and that measured is good (Table 3 ) for the $-\mathrm{N}$ treated plants, particularly as measurements of $\mathrm{CO}_{2}$ exchange were not made on the same plants and the integration over time and conditions is based on short-term measurements on a single leaf in the case of $\mathrm{CO}_{2}$ assimilation. However, the much greater calculated dry matter accumulation in $+\mathrm{N}$ treatments at both temperatures could be due to over-estimation of net photosynthesis or to inappropriate respiration rates. If the respiration of the high $\mathrm{N}$ plants was $50 \%$ of the assimilation (Ryle, Cobby, and Powell, 1976) then agreement of measured dry matter accumulation would be much closer but the $-\mathrm{N}$ treatment growth would be underestimated. The greater growth rate per unit of accumulated temperature of cold compared to warm-grown plants may be related to a smaller ratio of respiration to photosynthesis in the cold and not to the greater total light energy available. Clearly more detailed experimental data on the respiration rates in relation to assimilation are required at different rates of nitrogen supply and at different temperatures if total plant dry matter accumulation with $\mathrm{N}$ and temperature is to be fully understood.

\section{CONCLUSIONS}

Changes induced in the growth of young plants by different combinations of temperature and nitrate supply may be explained by reference to a simple qualitative model (Fig. 7). 
Potential growth rate is determined by temperature, the actual growth rate depends on the rate of supply of $\mathrm{N}$ and light energy (assuming $\mathrm{CO}_{2}$, other nutrients, water etc. to be non-limiting). Given an adequate $\mathrm{NO}_{3}^{-}$concentration at the root to maintain a high rate of $\mathrm{NO}_{3}^{-}$accumulation (hence the large pool of $\mathrm{NO}_{3}^{-}$) and adequate rates of $\mathrm{NO}_{3}^{-}$reduction, fast amino-acid synthesis results, shown by increased ${ }^{14} \mathrm{C}$ incorporation into amino acids and greater amino acid content of leaves. Consequently the rate of protein synthesis and the growth rate are at the maximum determined by the temperature. There is accumulation of nitrogen-containing compounds and proteins, giving a large nitrogen content in dry matter. Under these conditions competition for substrates, principally amino acids, is reduced and growth rate of both main-shoot leaves and of tillers is large; these organs then form a larger proportion of total plant material. Nitrogen deficiency decreases the $\mathrm{NO}_{3}^{-}$content and decreases the rate of amino-acid synthesis (shown by ${ }^{14} \mathrm{C}$ incorporation) and, therefore, the rate of protein synthesis is slowed and with it plant growth rate. Also the $\mathrm{N}$ content of dry matter decreases and the growth rate of tillers is slowed relatively more than that of main stems. As proportionately more carbohydrates than amino acids are synthesized, the mass of storage organs (roots and stems) increases relative to organs requiring large amounts of $\mathrm{N}$ and this alters the root/shoot (leaf) ratio.

In this concept cool temperature slows the rate of protein synthesis and thereby growth, and decreases the demand for nitrogen. However, the $\mathrm{NO}_{3}^{-}$uptake and reduction mechanisms are maintained whilst leaf expansion decreases so that proteins, pigments etc. accumulate in leaves supplied with abundant $\mathrm{N}$, increasing the content of $\mathrm{N}$ in dry matter. As leaves live longer, have assimilation rates only slightly smaller, and respire relatively less in cool- than warm-conditions, the growth rate per unit of accumulated temperature may be larger in cool conditions. From this model we suggest that regulation of growth by temperature occurs primarily at protein synthesis and on the supply of $\mathrm{NO}_{3}^{-}$to the plant which is dependent on the concentration at the root. Processes in carbon assimilation and carbohydrate synthesis are largely dependent on the development of the photosynthetic apparatus, which is a consequence of protein synthesis and on the light energy and $\mathrm{CO}_{2}$ supply.

\section{LITERATURE CITED}

BEEVERS, L., 1979. Nitrogen metabolism in plants. Edward Arnold, London.

DALE, J. E., 1979. Nitrogen supply and utilization in relation to development of the cereal seedling. In Nitrogen assimilation in plants. Eds E. J. Hewitt and C. V. Cutting. Academic Press, London. Pp. 153-63.

Durzan, D. J., and Steward, F. C., 1983. Nitrogen metabolism. In Plant physiology, a treatise. Volume VIII, Nitrogen metabolism. Ed. F. C. Steward. Academic Press, Orlando. Pp. 55-265.

KIRBY, E. J. M., 1985. Significant stages of ear development in winter wheat. In Wheat growth and modelling. Eds W. Day and R. K. Atkinson. Plenum Press, New York and London. Pp. 7-24.

Lambers, H., Simpson, R. J., Beilharz, V. C., and Dalling, M. J., 1981. Growth and translocation of $\mathrm{C}$ and $\mathrm{N}$ in wheat (Triticum aestivum) grown with a split root system. Physiologia plantarum, 56, 421-9.

Lawlor, D. W., Boyle, F. A., Kendall, A. C., and Keys, A. J., 1987a. Nitrate nutrition and temperature effects in wheat: enzyme composition, nitrate and total amino acid content of leaves. Journal of Experimental Botany, 38, 378-92.

YounG, A. T., KeYs, A. J., and Kendall, A. C., 1987b. Nitrate nutrition and temperature effects in wheat: photosynthesis and photorespiration of leaves. Ibid. 38, 393-408.

Kendall, A. C., and KeYS, A. J., 1987c. Nitrate nutrition and temperature effects in wheat: soluble components of leaves and carbon fluxes to amino acids and sucrose. Ibid. 38, 1091-1103.

Rorson, M. J., and Parsons, A. J., 1981. Respiratory efflux of carbon dioxide from mature and meristematic tissue of uniculm barley during 80 hours of continuous darkness. Annals of Botany, 48, 727-31. 
Ryle, G. J. A., Cobby, J. M., and Powell, C. E., 1976. Synthetic and maintenance respiratory losses of ${ }^{14} \mathrm{CO}_{2}$ in uniculm barley and maize. Ibid. 40,571 .

STULEN, I., 1986. Interactions between nitrogen and carbon metabolism in a whole plant context. In Fundamental, ecological and agricultural aspects of nitrogen metabolism in higher plants. Eds H. Lambers, J. J. Neeteson and I. Stulen. Martinus Nijhoff Publishers, Dordrecht. Pp. 26178.

Vesk, M., Possingham, J. V., and Mercer, F. V., 1965. The effect of mineral nutrient deficiencies on the structure of the leaf cells of tomato, spinach and maize. Australian Journal of Botany, $14,1-18$. 
